\title{
Wybory edukacyjno-zawodowe uczniów gimnazjów w tym uczniów ze specjalnymi potrzebami edukacyjnymi w kontekście kondycji doradztwa zawodowego
}

\begin{abstract}
Joanna Kozielska, Wybory edukacyjno-zawodowe uczniów gimnazjów w tym uczniów ze specjalnymi potrzebami edukacyjnymi w kontekście kondycji doradztwa zawodowego [Educational and occupational choices of secondary school students, including with special educational needs, in the context of the state of career counselling]. Interdyscyplinarne Konteksty Pedagogiki Specjalnej, nr 20, Poznań 2018. Pp. 123-141. Adam Mickiewicz University Press. ISSN 2300-391X. DOI: 10.14746/ikps.2018.20.06
\end{abstract}

The proposed text is an illustration of research conducted in the first half of 2016 years of empirical verification planning future educational and vocational secondary school and upper secondary youth in Gniezno. When analyzing the situation of the local labor market and its prospects for the group of respondents was done between other high school students, because they are in a few years will include the labor market and indirectly (now) affect its shape. The awareness of their plans but allows us to predict, and thus the possibility of remedying causing difficulties in the labor market. In proposed project groups of respondents they were done as teenagers of secondary schools, directors of secondary schools and the largest local employers. Article focuses on students with special educational needs and on issues concerning the condition of vocational education and educational and professional choices of young people, taken over their strategies in relation to the current needs of the local labor market.

KEY WORDS: planning for the future educational and professional, career counseling, labor market, youth, vocational education, students with special educational needs 


\section{Wybory edukacyjno-zawodowe w czasach permanentnej zmiany}

Permanentna zmiana rodząca szereg ambiwalencji i wieloznaczności wpisana w obraz współczesności wraz z niepewnością i koniecznością ciągłego podejmowania ryzyka, stawia człowieka wobec szeregu wyzwań życiowych i zawodowych ${ }^{1}$, a odmieniony po 1989 r. rynek pracy wymusza ponadto całe spektrum przedsięwzięć mających na celu wpasowanie się jednostek w jego nowe oblicze. Uniwersalne niegdyś formy drogi zawodowej - kraju stabilnej gospodarki nowoczesnej - kraju sprzed etapu transformacji ustrojowej, przeobrażone zostały w wachlarz szans i możliwości, obaw i ryzyka zawodowego, co obrazują np.: badania Magdaleny Piorunek $^{2}$, Lucyny Myszki-Strychalskiej ${ }^{3}$ i inne ${ }^{4}$.

Znając choćby lokalne właściwości rynku pracy, można się do takich zmian przygotować i na bieżąco na nie odpowiadać - dostosowując odpowiednio system kształcenia do potrzeb rynku pracy, do potrzeb pracodawców. Takie działania są działaniami wieloetapowymi i czasochłonnymi, ale mają szansę stać się czynnikami,

1 Z. Bauman, Ponowoczesność jako źródło cierpień, Wydawnictwo Sic!, Warszawa 2002; Z. Bauman, Razem osobno, Wydawnictwo Literackie, Kraków 2000; Z. Bauman, Życie na przemiat, Wydawnictwo Literackie, Kraków 2005; U. Beck, U. Społeczeństwo ryzyka. W drodze do innej nowoczesności, Wydawnictwo Naukowe Scholar, Warszawa 2002; A. Giddens, Nowoczesność i tożsamość. "Ja" i społeczeństwo w epoce późnej nowoczesności, Wydawnictwo Naukowe PWN, Warszawa 2001.

2 M. Piorunek, Projektowanie przyszłości edukacyjno-zawodowej w okresie adolescencji, Wydawnictwo Naukowe UAM, Poznań 2004.

${ }^{3}$ L. Myszka-Strychalska, Orientacje zawodowe młodzieży z zespołów szkół zawodowych, Wydawnictwo Naukowe UAM, Poznań 2016.

${ }^{4}$ J. Kozielska, Perspektywy i nowe rozwiazania $w$ doradztwie zawodowym. Coaching jako narzędzie pracy doradców zawodowych w kontekście idei lifelong learningu, „Studia Edukacyjne" 2015, nr 37; J. Kozielska, Adaptational difficulties of Polish economic emigrants in the context of globalisation processes, "Culture - Society - Education" 2017, No. 1 (11); A. Suchorab, Wptyw zadań z zakresu orientacji i poradnictwa zawodowego realizowanych $w$ szkole ponadgimnazjalnej na wybory edukacyjno-zawodowe studentów, "Szkoła - Zawód - Praca” 2012, nr 3; A. Suchorab, Plany edukacyjno-zawodowe i zatrudnieniowe uczniów szkół zawodowych, „Szkoła - Zawód - Praca” 2015, nr 10. 
które mogą redukować wiele problemów społecznych, jak bezrobocie, bieda czy ubóstwo. Do realizacji takiej koncepcji niezbędni są jednak kompetentni doradcy zawodowi.

Proponowany tekst jest ilustracją badawczą prowadzonych w pierwszym półroczu roku 2016 weryfikacji empirycznych dotyczących planowania przyszłości edukacyjno-zawodowej przez młodzież gimnazjalną oraz ponadgimnazjalną powiatu gnieźnieńskiego. Dokonując analizy sytuacji lokalnego rynku pracy i jego perspektyw, grupą respondentów uczyniono m.in. gimnazjalistów, w tym uczniów ze specjalnymi potrzebami edukacyjnymi, to oni bowiem za kilka lat wchodzić będą na rynek pracy i pośrednio (już teraz - poprzez swoje edukacyjne wybory) wpływają na jego kształt. Świadomość ich planów natomiast pozwala na przewidywanie, a tym samym możliwość przeciwdziałania sytuacjom powodującym trudności na rynku pracy. W relacjonowanym projekcie grupami respondentów uczyniono także młodzież szkół ponadgimnazjalnych, dyrektorów szkół ponadgimnazjalnych oraz największych lokalnych pracodawców. Cały projekt składał się z czterech modułów: pracodawca; gimnazjalista; uczeń/absolwent szkoły ponadgimnazjalnej; IV - dyrektor szkoły ponadgimnazjalnej ${ }^{5}$.

${ }^{5}$ Rozstrzygano następujące kwestie: 1 . Jakie plany edukacyjno-zawodowe mają gimnazjaliści z powiatu gnieźnieńskiego $\mathrm{w}$ tym uczniowie ze SPE? 2. Jak przedstawia się sytuacja na lokalnym rynku pracy? 3. Jaką rolę odgrywa przy wyborze kolejnego szczebla edukacyjnego gimnazjalny doradca zawodowy? „PANEL GIMNAZJALIŚCI": 1. Jak przedstawia się struktura społeczna gimnazjalistów z powiatu gnieźnieńskiego? (płeć, miejsce zamieszkania, wykształcenie rodziców, średnia ocen) 2. Jakie są plany edukacyjno-zawodowe gimnazjalistów? W tym uczniów z SPE? (Czy zamierzają kontynuować edukację? W jakim typie szkół zamierzają kontynuować edukację? W jakim typie klasy zamierzają kontynuować edukację? Jaki zawód wybrali? Czy gimnazjaliści biorą pod uwagę naukę w innym mieście? Co wiedzą i co sądzą o najbardziej pożądanych zawodach (zawody deficytowe dla regionu)? 3. Jak oceniają kwestie związane $\mathrm{z}$ doradztwem zawodowym w szkole? (Czy znają ofertę edukacyjną w Gnieźnie? Z czyjej pomocy korzystają, wybierając szkołę? Czym się kierują wybierając szkołę? Jakie asocjacje towarzyszą im w związku z poszczególnymi typami szkół? Jak oceniają poszczególne szkoły ponadgimnazjalne w Gnieźnie? Co oznacza dla nich zwrot "dobra praca”? „PANEL ZAWODOWCÓW" UCZEŃ/ABSOLWENT SZKOŁY PONADGIMNAZJALNEJ 1. Jak 
W niniejszym tekście koncentrować się będę na przede wszystkim na gimnazjalistach $w$ tym uczniach ze specjalnymi potrzebami edukacyjnymi.

Ze względu na specyfikę tematu badawczego dobór próby badawczej miał charakter losowy ${ }^{6}$. Badaniem zostali objęci gimnazjaliści $(\mathrm{N}=486) \mathrm{z}$ tego blisko $17,00 \%$ to uczniowie ze specjalnymi potrzebami edukacyjnymi (uczniowie $\mathrm{z}$ niepełnosprawnościami, uczniowie zagrożeni niedostosowaniem społecznym, uczniowie

przedstawia się struktura społeczna uczniów szkół ponadgimnazjalnych pod kątem płci i zawodu? 2. Czy uczniowie czują się przygotowani do podjęcia pracy zawodowej $w$ zawodzie, który zdobywają? 3. Co budzi ich największe obawy, jeśli chodzi o przejście z roli ucznia do roli pracownika? 4. Czy skorzystaliby z szansy wzięcia udziału w stażu, praktykach, kursie (bezpłatnie), które uzupełniłyby ich kwalifikacje zawodowe, dając możliwość lepszego zafunkcjonowania na rynku pracy? 5. Z jakich szkoleń, kursów skorzystaliby respondenci? 6. Czy w szkole jest doradca zawodowy? 7. Czy respondenci skorzystaliby ze szkolenia dotyczącego pisania dokumentów aplikacyjnych (CV, listu motywacyjnego) tak by być gotowym do szukania zatrudnienia? 8. Czy respondenci skorzystaliby $\mathrm{z}$ indywidulanego spotkania z doradcą zawodowym? DYREKCJA 1. Jakie są potrzeby szkół dotyczące wyposażenia/doposażenia pracowni? 2. Jakie kursy/szkolenia byłyby użyteczne dla nauczycieli nauki zawodu? 3. Jakie kursy/szkolenia można zaproponować uczniom ostatnich klas, by przygotować ich do optymalnego wejścia na rynek pracy? PRACODAWCA 1. Jaką branżę reprezentuje respondent? 2. Na jakim sprzęcie/na jakich maszynach/urządzeniach pracują zawodowcy w firmie? 3. Jaka jest liczba zatrudnionych $\mathrm{w}$ firmie osób (administracja/zawodowcy)? 4. Jak pracodawca określa sytuację na rynku pracy $w$ powiecie gnieźnieńskim? 5. Czy respondenci zamierzają zatrudnić $\mathrm{w}$ najbliższym czasie pracowników ( $\mathrm{w}$ ciągu najbliższych trzech lat)? 6. Ile osób zamierzają zatrudnić? 7. Na jakie stanowiska/w jakich zawodach zamierzają zatrudnić pracowników? 8. W jaki sposób przedsiębiorstwo poszukuje/poszukiwało pracowników? 9. Jak respondenci oceniają przygotowanie zawodowe absolwentów zasadniczych szkół zawodowych? 10. Jak respondenci oceniają przygotowanie zawodowe absolwentów techników? 11. Jaką wiedzę, kompetencje, umiejętności powinien mieć pracownik, którego planuje zatrudnić respondent? 12. Jakie szkolenie/szkolenia/kursy/staże powinni przejść absolwenci lub uczniowie $\mathrm{w}$ trakcie nauki, by $\mathrm{w}$ pełni fachowo wykonywać powierzone im obowiązki zawodowe w nowym miejscy pracy? 13 . W jakim zakresie firma współpracuje w ze szkołami zawodowymi?

${ }^{6}$ E. Babbie, Badania spoteczne w praktyce, Wydawnictwo Naukowe PWN, Warszawa 2005. 
niedostosowani społecznie oraz uczniowie bez orzeczeń o potrzebie kształcenia specjalnego, bez opinii poradni psychologiczno-pedagogicznych, wobec których szkoła podejmuje działania o charakterze pomocowym, socjoterapeutycznym, terapeutycznym, rozwijającym uzdolnienia i inne), uczniowie szkół ponadgimnazjalnych $(\mathrm{N}=503)$ dyrektorzy szkół ponadgimnazjalnych $(\mathrm{N}=6)$ oraz najwięksi pracodawcy z powiatu gnieźnieńskiego $(\mathrm{N}=14)$ i doradcy zawodowi $(\mathrm{N}=22)$.

$\mathrm{W}$ omawianym projekcie jako podstawowa zastosowana została: metoda sondażu diagnostycznego. Techniką, która wpisuje się w metodę badań sondażowych, jest ankietowanie, do którego posłużono się narzędziem badawczym, którym uczyniono kwestionariusz ankiety. Uzupełniająco w omawianym projekcie wykorzystano metodę analizy treści ${ }^{7}$, którymi uczyniono lokalną prasę tradycyjną (w wersji drukowanej) i internetową oraz opracowania tematyczne poczynione przez Powiatowy Urząd Pracy w Gnieźnie i inne instytucje.

\section{Edukacyjno-zawodowe wybory młodzieży}

Pojawiające się kryzysy sektora pracy nie są już tylko problemem dorosłych, związków zawodowych, ekonomistów i polityków. Osiągnęły one w ciągu ostatnich lat samo centrum problemów młodego pokolenia. Adolescencja przestała być ochronnym okresem przygotowań (moratorium), stała się okresem emancypowania w problemach rynku pracy.

Nauka i praca są zasadniczymi elementami, poprzez które konstruuje się społeczny profil biografii i dokonuje się wejście młodzieży w zróżnicowane tory życia zawodowego charakteryzujące drogi życiowe dorosłych ${ }^{8}$. Warto zauważyć, iż zawodzi aktualnie para-

${ }^{7}$ K. Żegnałek, Metody $i$ techniki stosowane w badaniach pedagogicznych, Wyższa Szkoła Pedagogiczna Towarzystwa Wiedzy Powszechnej w Warszawie, Warszawa 2008.

${ }^{8}$ M. Piorunek, op. cit., s. 27. 
dygmat podmiotowego rozmieszczania się $\mathrm{w}$ wachlarzu zaprojektowanych możliwości edukacyjno-zawodowych, która jeszcze kilkanaście lat temu gwarantowała przewidywalność doświadczeń zawodowych na rodzimym rynku pracy. Dzisiejsza młodzież staje $\mathrm{u}$ progu dorosłego życia w trudnych warunkach rynkowych i ekonomiczno-społecznych, wobec narastającej konkurencyjności, wymogów dużej mobilności i elastyczności zawodowej. Nie dziwi zatem fakt, iż ciągu ostatnich kilkunastu lat można zaobserwować dynamiczny wzrost zainteresowania tematyką związaną z edukacyjno-zawodowymi wyborami ludzi. Wyrazem takiego stanu rzeczy są liczne prace naukowo-badawcze (do niektórych odwołam się poniżej), w których rozważania swe podjęli m.in. Augustyn Bańka, Stefan Michał Kwiatkowski, Agnieszka Cybal-Michalska, Magdalena Piorunek, Ewa Solarczyk-Ambrozik, Ryszard Parzęcki, Anna Suchorab, Elżbieta Kasprzak, Katarzyna Klimkowska, Andrzej Miś, Zdzisław Wołk, Alicja Kargulowa, Daniel Kukla, Elżbieta Turska, Iwona Mandrzejewska-Smól, Bożena Wojtasik, Anna Rajchel, Jerzy Ambroży, Dobromir Dziewulak, Wioleta Duda i inni, uwzględniając $w$ tym także raporty ministerialne i opracowania czynione przez Instytut Badań Edukacyjnych czy Ośrodek Rozwoju Edukacji itp.

W badaniu gimnazjalistów, które uczyniono dominującym aspektem niniejszego artykułu, udział wzięło 256 uczennic i 230 uczniów (wszyscy to uczniowie ostatniej klasy gimnazjum) w tym 68 uczniów to uczniowie ze specjalnymi potrzebami edukacyjnymi, z czego $40,00 \%$ stanowiły uczennice (27 osób) a 60,00\% uczniowie (41osób). Największą aktywnością w wypełnianiu ankiety ${ }^{9}$ wykazali się uczniowie z gimnazjów w Gnieźnie, aktywność związana z wypełnieniem narzędzia przez resztę gimnazjalistów z powiatu była niska, podobnie jak uczniów z dwóch gnieźnieńskich gimnazjów prywatnych. Zdecydowana większość gimnazjalistów (68,30\%) biorących

\footnotetext{
${ }^{9}$ Ankietę wypełniano w szkolnej pracowni informatycznej w obecności badacza i pedagoga - uczniowie nie zawsze byli świadomi kategorii do której należeliSPE/ brak SPE- kafeterię dotyczące SPE uzupełniał pedagog po zakończonym przez ucznia badaniu.
} 
udział w badaniu to zatem mieszkańcy miasta, tylko co trzeci mieszka na wsi $(31,70 \%)$. Struktura wykształcenia rodziców respondentów jest bardzo zróżnicowana, ponad 50,00\% ojców to absolwenci zasadniczych szkół zawodowych i techników. Jeśli chodzi natomiast o wykształcenie matek, znacznie częściej niż ojcowie osiągnęły one wykształcenie wyższe (26\% matek w stosunku do $14,00 \%$ ojców), grupa matek absolwentek zasadniczych szkół zawodowych także utrzymuje się na wysokim poziomie (co trzecia matka). Co piąty gimnazjalista nie wie, jaką szkołę ukończyli jego rodzice, co budzić powinno obawy. Wiedza na temat wykształcenia rodziców to jeden z pierwszych etapów doradztwa zawodowego preorientacji zawodowej, rozbudzenie ciekawości poznawczej dotyczącej życia zawodowego i edukacyjnych wyborów najbliższych nie tylko rodziców, ale i dziadków, rodzeństwa itd.

Uczniowie stanowiący grono respondentów uzyskali zróżnicowane średnie ocen. Najwięcej z nich (prawie 20,00\%) to osoby, które

Wykres 1. Średnia ocen respondentów

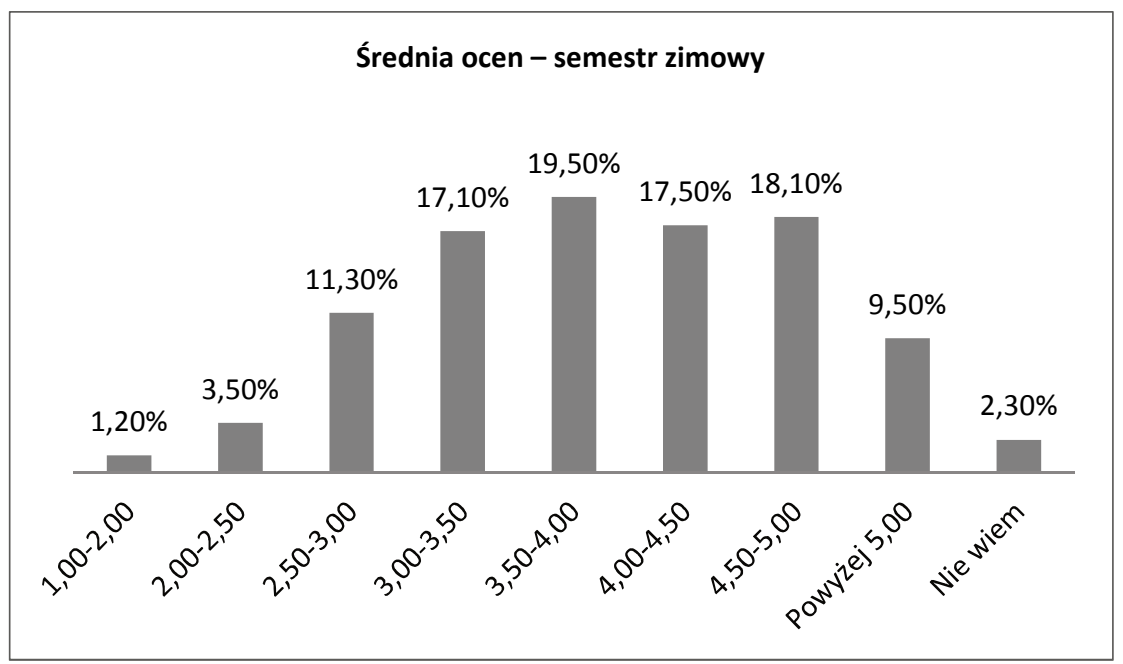

Źródło: Opracowanie własne 
w semestrze zimowym roku szkolnego 2015/2016 osiągnęły średnią ocen między 3,5 a 4,0, niemalże równoliczne grupy stanowią osoby ze średnią 3,00-3,50 oraz 4,0 i 4,5 (po ok 17,00\%). Co piaty uczeń osiągnął średnią między 4,50-5,00.

15 osób nie wie, gdzie lub nie zamierza kontynuować dalszej edukacji, natomiast blisko 97,00\% respondentów, z relacjonowanej próby badawczej, zamierza kształcić się dalej. Wyniki te nie różnicuje statystycznie kwestia kategorii specjalnych potrzeb edukacyjnych. Plany gimnazjalistów są już w zasadzie sprecyzowane (wykres 2). Ponad 50,00\% uczniów deklaruje, iż zna ofertę, ale potrzebuje wsparcia informacyjnego w zakresie oferty edukacyjnej w powiecie gnieźnieńskim. Co dziesiąty stwierdza, że nie ma żadnej wiedzy na temat oferty edukacyjno-zawodowej $\mathrm{w}$ mieście, $37,40 \%$ deklaruje, że ma pełną wiedzę na temat oferty. Co ciekawe, nawet nie znając oferty, deklarują, co zaprezentowano powyżej, że już wybrali przyszłą szkołę. Prezentowane badanie przeprowadzono pół roku przed możliwością dokonania rzeczywistego wyboru kolejnego szczebla kształcenia. Jak się okazało, po zestawieniu badań z lutego i danych Starostwa Powiatowego w Gnieźnie z danymi z rekrutacji (lipiec), okazało się że (prognozowane) wybory pokryły się z realnymi wyborami absolwentów gimnazjów (43,00\% absolwentów zdecydowało się na kontynuowanie kształcenia w liceum ogólnokształcącym, 37,00\% w technikum, a co piąty wybrał szkołę zawodową). Deklaracje z lutego (wykres 2) spowodowały jednak, iż władze powiatu ograniczyły liczbę oddziałów w liceach ogólnokształcących. Mając świadomość specyfiki powiatowego rynku pracy i losów absolwentów szkół ogólnokształcących, prowadzono także kampanię pt.: "Zawodówka jest OK”, co skutkowało wyższym naborem na rok szkolny 2016/2017 do techników i szkół zawodowych w porównaniu do lat poprzednich.

W deklaracjach z lutego - blisko 40,00\% gimnazjalistów planowała wybrać liceum ogólnokształcące, choć co dziesiąty nie zdecydował jeszcze w jakim typie klasy chce się kształcić (największym powodzeniem cieszyły się klasy humanistyczne i o profilu obronnym). Co trzeci badany zamierzał kontynuować naukę w technikum, a tylko 
Wykres 2. Plany edukacyjne młodzieży gimnazjalnej powiatu gnieźnieńskiego

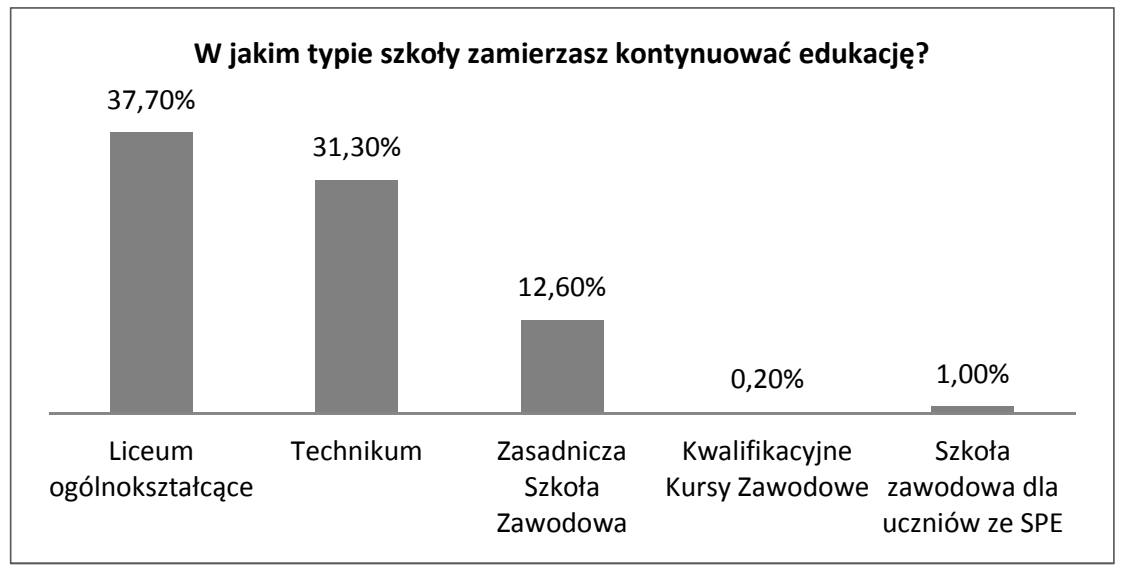

Źródło: opracowanie własne

co dziesiąty w zasadniczej szkole zawodowej. Wybory edukacyjno-zawodowe uczniów ze specjalnymi potrzebami edukacyjnymi wyglądały dość podobnie jednak więcej z nich deklarowało wybór technikum i szkoły zawodowej niż liceum ogólnokształcącego. 22,00\% zdecydowało się na szkołę zawodową dokładnie tyle samo na liceum ogólnokształcące, a co drugi z uczniów zdecydował się na technikum (56,00\%). Zdecydowana większość wybierających ofertę „branżową" (technikum i zasadniczą szkołę zawodową) stanowili chłopcy, tylko 5\% stanowiły dziewczęta (ich udział w grupie uczniów bez SPE był wyższy - na wybór oferty zawodowej lub technicznej wskazywała co szósta badana).

Wybór szkoły nie jest związany z wykształceniem rodziców, w przypadku grupy respondentów nie można mówić o sytuacji powielania skryptu życiowego i modelu edukacji, można zaobserwować natomiast fakt, iż respondenci przy założeniu, że wybierają liceum, by w efekcie kontynuować kształcenie na studiach, chcą osiągnąć wykształcenie wyższe niż pokolenie rodziców. Co znamienne, uczniowie decydują się na liceum ogólnokształcące niezależ- 
Wykres 3. Wyniki egzaminów gimnazjalnych

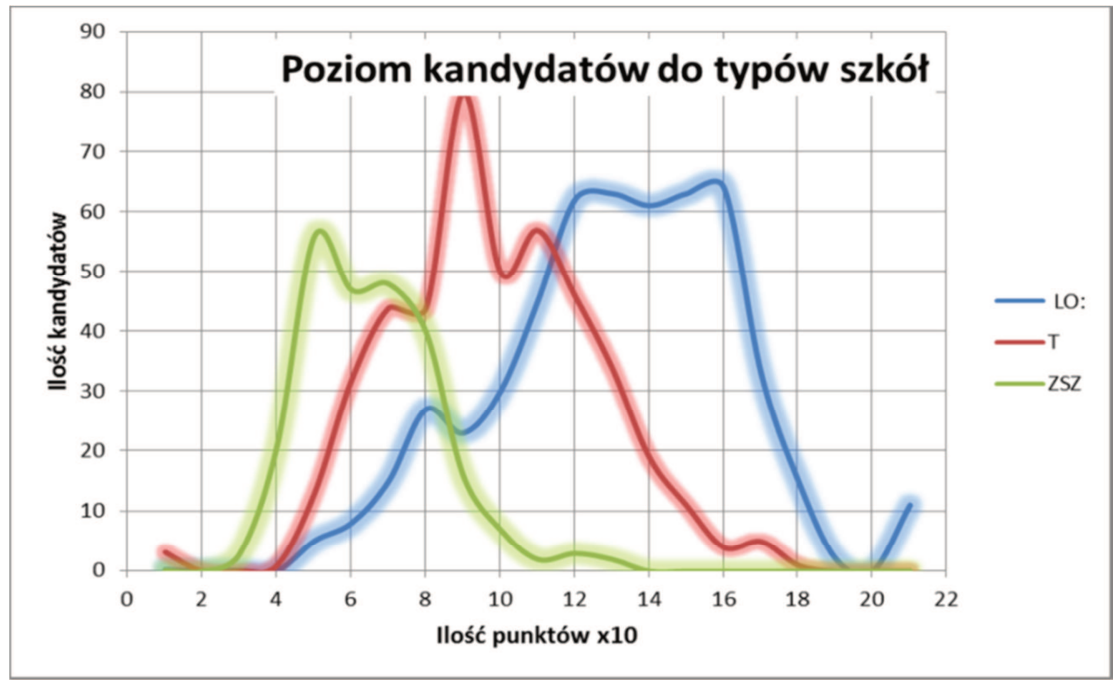

Źródło: Opracowanie własne na podstawie danych Starostwa Powiatowego w Gnieźnie

nie od średnich uzyskiwanych ocen, co oznacza, że tak samo często na liceum decydują się zarówno bardzo dobrzy jak i bardzo słabi uczniowie, szkołę średnią wieńczącą się maturą (technikum i liceum ogólnokształcące wybrało 78,00\% uczniów ze SPE).

Potwierdzają to dane zaprezentowane poniżej, które stanowią egzemplifikację wyników testów gimnazjalnych w odniesieniu do szkoły ponadgimnazjalnej, do której został przyjęty absolwent gimnazjum.

Uczniowie (SPE i bez), którzy deklarują, że naukę kontynuować będą w szkołach zawodowych i technikach, w zdecydowanej większości przypadków (72,00\%) potrafili wskazać i nazwać zawód, który wybrali, ale byli i tacy $(38,00 \%)$ którzy wskazywali na zawody, których nie można zdobyć w wymienionych szkołach: np. psycholog, terapeuta, lekarz, nauczyciel, kryminolog, prawnik, komentator sportowy itp. Zdecydowana większość z nich $(64,00 \%)$ nie potrafiła także wskazać jakie predyspozycje są potrzebne do tego, 
by wykonywać wybrany przez nich zawód. Ponad 62,00\% uczniów nie potrafiło też określić, na jakie zawody jest dziś na rynku pracy (choćby lokalnym) zapotrzebowanie. Decydują zatem w zasadzie w ciemno.

Rozterki związane z wyborem zawodu są związane z faktem, iż w szkole słabo widoczna jest działalność doradców zawodowych. Tyle samo uczniów uważa, że w szkole doradca jest, tyle samo twierdzi, że nie lub nie wie czy jest. Nieco lepiej w tym aspekcie wypadli uczniowie ze SPE - w 4 z 13 biorących udział w badaniu szkołach uczniowie ze SPE odbywają zajęcia z doradcą zawodowym $w$ ramach godzin z puli dyrektora. $67,00 \% \mathrm{z}$ nich wiedziało, że w szkole jest doradca zawodowy. Obowiązek ustawowy oraz rozpoznanie kwestii w biorących udział w badaniu szkołach daje pewność, by twierdzić, że we wszystkich ankietowanych szkołach jest osoba organizująca zadania $\mathrm{z}$ zakresu doradztwa zawodowego i realizująca (być może słabo widoczne) działania uwzględnione w Wewnątrzszkolnym Systemie Doradztwa Zawodowego. Tak niska identyfikacja roli doradcy zawodowego związana jest to z faktem, iż zajęcia z zakresu doradztwa zawodowego/preorientacji zawodowej organizowane są incydentalnie, bez harmonogramu, często w odpowiedzi na absencję innych nauczycieli przedmiotowych. Poza tym kwestie merytoryczne zajęć nie zawsze kojarzone są przez uczniów jako zajęcia z doradztwa zawodowego. Np. doradca zawodowy, który jest także pedagogiem lub nauczycielem innego przedmiotu, w konkretnej szkole prowadzi zajęcia związane $\mathrm{z}$ samopoznaniem - w świadomości gimnazjalisty są to zajęcia z pedagogiem, wychowawcą - nie doradcą zawodowym.

Co budzi niepokój - zdecydowana większość uczniów (bez SPE) $(68,00 \%)$ zaznacza, iż nie korzystała z pomocy doradcy zawodowego i nie uczestniczyła w zajęciach z zakresu doradztwa zawodowego. Blisko 70,00\% respondentów (uczniowie ze SPE i bez) deklaruje, że korzysta z pomocy innych przy podejmowaniu decyzji o wyborze przyszłej szkoły i zawodu, 30,00\% wskazuje na pełną w tym zakresie samodzielność. Osobami znaczącymi w kwestii podejmowania wyborów o charakterze edukacyjnym są najczęściej rodzice 
(78,60\%) na wysokim drugim miejscu plasuje się internet $(31,30 \%)$, dalej koledzy $(28,40 \%)$ i inni członkowie rodziny $(25,50 \%)$, rodzeństwo $(24,30 \%)$, doradcy zawodowi $(17,50 \%)$, nauczyciele $(11,50 \%)$ i wychowawca $(8,00 \%)$. Ten fragment badań pokazuje, iż w aspekcie doradztwa zawodowego znacząca rolę odgrywają rodzice, dlatego dorady zawodowi powinni pracować także $\mathrm{z}$ nimi - w końcu to $u$ nich młodzi szukają wsparcia. Rodzice mogą nie być kompetentni w zakresie doradztwa zawodowego, mogą nie wiedzieć, że w szkole jest doradca, a tym samym nie pokierują dziecka do niego. Dlatego sami winni stać się odbiorcami prelekcji, warsztatów o tematyce dotyczącej pomagania dzieciom $\mathrm{w}$ wyborze zawodu.

Wykres 4. Doradca zawodowy w gimnazjum

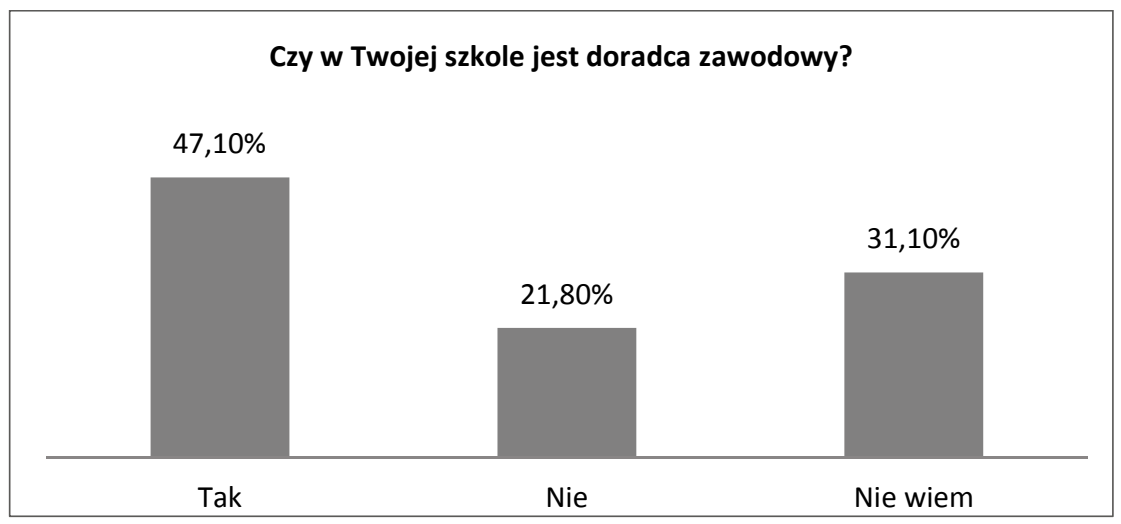

Źródło: opracowanie własne

Młodzi deklarują, iż wybierając szkołę, sugerują się swoimi zainteresowaniami, faktem, iż po wybranej szkole będą mieli konkretny zawód i dobrą pozycję na rynku pracy oraz tym, iż po szkole, na którą się zdecydowali, będą mogli iść na studia. Jak w wielu opracowaniach wskazują badacze wybór liceum i dalej studiów, to swoista odpowiedź na trudne czasy, to rodzaj przeczekania i danie 
sobie szansy na odroczenie decyzji o życiu zawodowym ${ }^{10}$. Ponad $80,00 \%$ badanych stwierdza, iż wybiera szkołę, ba ta odpowiada ich zainteresowaniom (a co ciekawe ponad połowa nie potrafiła określić czym się interesuje i w czym jest dobra). Prawie połowa badanych określa, iż w wyborze szkoły zadecydował fakt, iż po jej zakończeniu można mieć dobrą pracę lub kontynuować naukę na wyższych uczelniach. Blisko co piąty ankietowany (SPE i bez) wybrał daną szkołę bo jest „fajna” lub z uwagi na fakt, iż znajduje się blisko jego miejsca zamieszkania $(21,80 \%)$. Ponad połowa respondentów nie potrafi też powiedzieć, którą z lokalnych szkół zawodowych, technicznych i liceów ogólnokształcących uważają za najlepszą. Co dziesiąty badany zasugerował się faktem, że wybraną szkołą interesują się jego koleżanki/koledzy lub już się w niej uczą, a co dwudziestą osobę do konkretnego wyboru namówili rodzice.

Gimnazjaliści dokonali wyboru na chybił trafił - jak zadeklarowali - bez znajomości potrzeb lokalnego (nie mówiąc o regionalnym, ogólnopolskim) rynku pracy. Wykaz branż zidentyfikowanych jako branże o największym potencjale rozwojowym i/lub branż strategicznych dla województwa wielkopolskiego oraz barometr zawodów i specjalności wskazuje na poziomie regionu 44 zawody deficytowe. Wśród nich przeważającą grupę stanowią te zawody, których podjęcie wiąże się z wymogiem posiadania wykształcenia zawodowego (24 zawody) lub technicznego. Zawody wskazane jako deficytowe na obszarze powiatu gnieźnieńskiego to: administratorzy systemów komputerowych, analitycy, testerzy i operatorzy systemów teleinformatycznych, betoniarze i zbrojarze, blacharze samochodowi, cieśle i stolarze budowlani, dekarze i blacharze budowlani, doradcy finansowi i inwestycyjni, elektromechanicy i elektromonterzy, fryzjerzy, graficy komputerowi, hydraulicy, inżynierowie mechanicy, kelnerzy i barmani, kierowcy ciągnika siodłowego, kierownicy budowy, koordynatorzy projektów unij-

${ }^{10}$ M. Piorunek, op. cit.; J. Kozielska, Perspektywy i nowe rozwiazania...; J. Kozielska, Adaptational difficulties of Polish economic emigrants in the context of globalisation processes Culture - Society - Education No. 1 (11) 2017 Poznań; A. Suchorab, Wptyw zadań...; A. Suchorab, Plany edukacyjno-zawodowe... 
nych, krawcy i pracownicy produkcji odzieży, kucharze, lakiernicy samochodowi, lekarze, malarze budowlani, mechanicy maszyn i urządzeń, mechanicy pojazdów samochodowych, monterzy instalacji budowlanych, murarze, nauczyciele praktycznej nauki zawodu, nauczyciele przedmiotów zawodowych, obuwnicy, opiekunowie osoby starszej lub niepełnosprawnej, pielęgniarki, pomoce kuchenne, posadzkarze, pracownicy ds. rachunkowości i księgowości, projektanci i administratorzy baz danych, przedstawiciele handlowi, robotnicy budowlani, robotnicy obróbki drewna i stolarze, rolnicy i hodowcy, samodzielni księgowi, spawacze metodą MIG/MAG, spawacze metodą TIG, specjaliści automatyki i robotyki, specjaliści ds. organizacji produkcji, specjaliści ds. rynku nieruchomości, specjaliści ds. zastosowań informatyki, szefowie kuchni, tapicerzy, technicy elektrycy, technicy mechanicy, tynkarze. Zdecydowana większość zawodów wskazanych jako deficytowe to zawody, do których przygotowują zasadnicze szkoły zawodowe (branżowe od roku szkolnego 2017/2018) i technika. Zatem wybory uczniów ze SPE zdają się bardziej wpisywać w specyfikę lokalnego i regionalnego rynku pracy.

\section{Doradcy zawodowi a uczniowie ze specjalnymi potrzebami edukacyjnymi}

Kondycja doradztwa zawodowego pozostawia wiele do życzenia. Zapytano doradców w powiecie $(\mathrm{N}=22)$ czy w ich szkołach są uczniowie ze SPE. Zdecydowania większość 97,00\% określiła, że tak. Co zastanawiające jednak, tylko co szósty z nich jest członkiem zespołu organizującego pomoc psychologiczno-pedagogiczną, zatem na poziomie organizacyjnym niewielu $z$ nich ma wpływ na plan pracy doradczej, a przecież zajęcia związane z wyborem kierunku kształcenia i zawodu oraz planowaniem kształcenia i kariery szkolnej są jedną z form organizowana pomocy psychologiczno-pedagogicznej. Specyfika pracy doradcy zawodowego z osobą np.: z niepełnosprawnością wynikać winna $\mathrm{z}$ faktu, iż praca zawodowa 
pełni funkcję rehabilitacji - ma na celu uzyskanie zatrudnienia, jego utrzymanie i awans w odpowiedniej pracy oraz integrację społeczną. Podjęcie przypadkowej lub niewłaściwej decyzji zawodowej ma dla osób z niepełnosprawnościami niesie za sobą poważne konsekwencje, a mianowicie narażanie na zbędny wysiłek związany z uzyskaniem kwalifikacji zawodowych, który nie zaowocuje podjęciem pracy, co spowodować może rozgoryczenie i rezygnację z dalszej rehabilitacji zawodowej i aktywności zawodowej. Tylko $54,00 \%$ doradców zawodowych $\mathrm{w}$ omawianej grupie ma formalne wykształcenie, $8,00 \%$ potrafiło wskazać więcej niż 10 zawodów z powiatowej oferty natomiast aż $94,00 \%$ posługuje się testami przy czym żaden z doradców zawodowych nie miał przygotowania psychometrycznego czy stosownej certyfikacji.

\section{"Projekt życia, projekt kariery - projektem na chybił trafił"}

Strategie projektowania przyszłości są konstruktem teoretycznym. W specyficzny sposób wiążą projektowanie poszczególnych etapów drogi edukacyjno-zawodowej z ich bezpośrednim rozgrywaniem w praktyce społecznej, to jest "weryfikacją założeń preparacyjnych $w$ toku konkretnych działan"11. Do wymienionych przez M. Piorunek strategii należą:

- strategia kondensacji („zwężania pola wyborów”),

- strategia addytywna (,układanie puzzli"),

- strategia stochastyczna (,wyboru na chybił trafił” albo „zdania się na innych"),

- strategia aktualistyczna, która występować może jako strategia temporyzacji wyrażającej się w słowach „przyjdzie czas będzie rada” lub jako strategia pasywna, której motto to słowa „nie widzę dla siebie perspektyw",

- strategia asekuracyjna („,lepszy wróbel w garści”).

${ }^{11}$ M. Piorunek, op. cit., s. 56. 
Pierwsza z wymienionych powyżej strategii, strategia konden-
sacji

wiąże się z wczesnymi silnie sprecyzowanymi orientacjami edukacyjnymi i stosunkowo wczesnym skrystalizowaniem się zasadniczych zrębów orientacji zawodowej. (...) Częściej tego typu sytuacja dotyczy osób odnoszących sukcesy edukacyjne, mających wysokie aspiracje edukacyjne ${ }^{12}$.

Kolejna, z wymienionych strategii czyli strategia addytywna jest wyrazem

ukształtowanych orientacji edukacyjnych przy płynnej, niestabilnej sytuacji w obrębie orientacji zawodowej (...) dodawaniu poszczególnych elementów szeroko pojętego projektu własnej przyszłości (...) osoba na przykład wyraźnie aspiruje do uzyskania wykształcenia wyższego, ale nie bardzo wie, w jakiej dziedzinie, na kolejnych etapach kształcenia formułuje coraz to inne projekty zawodowe ${ }^{13}$.

Strategia stochastyczna, to strategia będąca rezultatem

niesprecyzowanych orientacji edukacyjnych i podobnie niedookreślonych orientacji zawodowych. (...) dotyczy osób niezdecydowanych, nie mających pomysłu na kształt swojej biografii zawodowej ${ }^{14}$.

Strategia asekuracyjna natomiast jest wyrazem

lepiej ukształtowanych orientacji zawodowych, które dodatkowo są urealniane przez pryzmat chronologicznie później rozwijających się orientacji edukacyjnych, a ostateczne decyzje zapadają w odniesieniu do biograficznych wymiarów obciążonych stosunkowo najmniejszym ryzykiem porażki ${ }^{15}$.

\footnotetext{
12 Ibidem, s. 57.

13 Ibidem, s. 58.

14 Ibidem, s. 59.

15 Ibidem, s. 60.
} 


\section{Podsumowanie}

Odwołując się do problemów badawczych projektu, które sformułowano w następujący sposób: 1. Jakie plany edukacyjno-zawodowe mają gimnazjaliści z powiatu gnieźnieńskiego w tym uczniowie ze SPE? 2. Jak przedstawia się sytuacja na lokalnym rynku pracy? 3. Jaką rolę odgrywa przy wyborze kolejnego szczebla edukacyjnego gimnazjalny doradca zawodowy? - można zauważyć, iż zdecydowana większość badanych zamierza kontynuować naukę w liceach ogólnokształcących, choć uczniowie ze SPE częściej wskazują na technika i szkoły zawodowe niż ich szkolni koledzy i koleżanki. Wybory edukacyjne, a w konsekwencji zawodowe młodzieży gimnazjalnej $\mathrm{z}$ relacjonowanej grupy $\mathrm{w}$ tym młodzieży ze specjalnymi potrzebami edukacyjnymi zdają się być osadzone w strategii stochastycznej oraz asekuracyjnej. Młodzi ludzie zdają się w kwestii planowania przyszłości edukacyjno-zawodowej polegać na opinii innych i aktualnych trendach (coroczne wybory liceów, co do popularności kierunków zawodowych, w przypadku powiatu wybierano w zasadzie tylko trzy zawody: ekonomista, fryzjer, zawody budowlane i mechaniczne/mechatroniczne, które to wpisywać się będą $\mathrm{w}$ zawody $\mathrm{w}$ równowadze $\mathrm{z}$ uwagi na powielające się wybory kilku roczników gimnazjalistów), niewpisujących się niestety w lokalny (lub regionalny) rynek pracy, przez co optymalizacja trendów choćby w lokalnym wymiarze staje się wyzwaniem. Decyzje podejmują bez znajomości oferty szkolnictwa ponadgimnazjalnego, bez znajomości siebie (mocne, słabe strony, zainteresowania) oraz bez znajomości specyfiki regionalnego czy lokalnego rynku pracy. Niezbyt optymistyczne w tym kontekście są także kwestie dotyczące kondycji doradztwa zawodowego. Ponad połowa doradców nie ma stosownego merytorycznego przygotowania i realnego wpływu na częstotliwość i program zajęć z preorientacji zawodowej. Nie dziwi zatem fakt, iż decydującą rolę $\mathrm{w}$ kwestii doradzania w wyborze zawodu mają rodzice. Uczniowie ze SPE zdaja się swoimi wyborami edukacyjno-zawodowymi celniej trafiać w potrzeby rynku pracy. Ciekawe, czy jest to wynikiem doradztwa zawodowego, które 
z tą kategorią uczniów dzieje się częściej, czy być może wynikiem stereotypu poprzedzonego socjalizacją: uczeń z problemem - absolwent - idealny kandydat do szkolnictwa zawodowego, które w opiniach respondentów (z grupy gimnazjalistów) jawi się jako oferta dla słabych, mało ambitnych. Co przecież bardzo mylące, gdyż, co zaznacza S.M. Kwiatkowski, szkolnictwo zawodowe i techniczne jest szkolnictwem pełnym wyzwań, trudnym, wymagający -- uczeń uczy się j. polskiego i matematyki, a także licznych przedmiotów zawodowych i odbywa dodatkowo praktyki.

\section{Bibliografia}

Babbie E., Badania społeczne w praktyce, Wydawnictwo Naukowe PWN, Warszawa 2005.

Bauman Z., Ponowoczesność jako źródto cierpień, Wydawnictwo Sic!, Warszawa 2002.

Bauman Z., Razem osobno, Wydawnictwo Literackie, Kraków 2000.

Bauman Z., Życie na przemiat, Wydawnictwo Literackie, Kraków 2005.

Beck U., Społeczeństwo ryzyka. W drodze do innej nowoczesności, Wydawnictwo Naukowe Scholar, Warszawa 2002.

Giddens A., Nowoczesność i tożsamość. "Ja" i społeczeństwo w epoce późnej nowoczesności, Wydawnictwo Naukowe PWN, Warszawa 2001.

Giermanowska E., Bezrobocie młodzieży jako problem społeczny, [w:] Społeczności lokalne wobec problemu bezrobocia młodzieży, red. E. Giermanowska, M. Racław-Markowska, Instytut Spraw Publicznych, Warszawa 2003.

Grewiński M., Bezrobocie i dezaktywizacja młodzieży, jako problem polityki społecznej, SIC! http:/ / sic.to/indexpl.php?page=1244 [dostęp: 15.05.2015]. http:/ / europa.eu. int/comm/eurostat/[dostęp: 15.05.2015].

Kozielska J., Perspektywy $i$ nowe rozwiazania w doradztwie zawodowym. Coaching jako narzędzie pracy doradców zawodowych w kontekście idei lifelong learningu, „Studia Edukacyjne" 2015, nr 37, Poznań 2015.

Kozielska J. Adaptational difficulties of Polish economic emigrants in the context of globalisation processes," Culture - Society - Education" 2017, No. 1 (11).

Kozielska J., Coaching kariery w kontekście lifelong learningu, [w:] Lifelong learning, red. V. Tanaś, W. Welskop, Wydawnictwo Naukowe Wyższej Szkoły Biznesu i Nauk o Zdrowiu, Łódź 2015.

Kozielska J., Planowanie przyszłości edukacyjno-zawodowej przez młodzież gimnazjalna w kontekście aktualnych potrzeb rynku pracy, "Społeczeństwo i Edukacja” 2016, 21(2). 
Kozielska J., Transnacjonalny wymiar poradnictwa i wsparcia społecznego. Kazus Polaków pracujacych w krajach Unii Europejskiej, [w:] W kręgu działań pomocowych i poradniczych, red. J. Kozielska, A. Skowrońska-Pućka, Wydawnictwo Naukowe UAM, Poznań 2016.

Krzychała S., Projekt życia. Młodzież w perspektywie badań rekonstrukcyjnych, Wydawnictwo Naukowe Dolnośląskiej Szkoły Wyższej Edukacji TWP, Wrocław 2007.

Kuźnik M., Projektowanie własnego życia jako forma dziatalności u progu dorostości, [w:] Szanse i zagrożenia rozwoju w okresie dorostości, red. A. Brzezińska, K. Appelt, J. Wojciechowska, Wydawnictwo Fundacji Humaniora, Poznań 2002.

Mlonek K., Młodzież na rynku pracy w Polsce w świetle badań. Warszawa 1996, Młodzi na rynku pracy. Pod lupą; ManpowerGroup, 2014, http://efl.pl/wpcontent/ uploads/2016/08/EFL_MLODZI_PRACA_RAPORT_www.pdf [dostęp: 12.12.16].

Pilch T., Zasady badań pedagogicznych, Wydawnictwo „Żak” Warszawa 1995.

Piorunek M., Młodzież w świecie wspótczesnym. Z badań orientacji biograficznych młodych okresu transformacji, Wydawnictwo „Rys”, Poznań 2004a.

Piorunek M., Edukacja i praca jako komponenty tożsamości człowieka w przestrzeni postnowoczesności, [w:] Modrzewski, J., Śmiałek, M., J., Wojnowski, K. Relacje podmiotów w lokalnej przestrzeni edukacyjnej (Inspiracje), UAM - Wydział Pedagogiczno-Artystyczny, Kalisz - Poznań 2008b.

Piorunek M., Edukacja i praca w cyklu życia człowieka, [w:] Edukacja wobec tożsamości społecznej, red. E. Gaweł-Luty, J. Kojkoł, Wydawnictwo HARMONIA, Gdańsk 2008a.

Piorunek M., Projektowanie przyszłości edukacyjno-zawodowej w okresie adolescencji, Wydawnictwo Naukowe UAM, Poznań 2004b.

Siwko M., Młodzież polska w integrującej się Europie, Wydawnictwo Uczelniane Politechniki Koszalińskiej, Koszalin 2006.

Solarczyk-Ambrozik E., Ksztatcenie ustawiczne w perspektywie globalnej i lokalnej Między wymogami rynku a indywidualnymi strategiami edukacyjnymi, Wydawnictwo Naukowe UAM, Poznań 2004.

Suchorab A., Plany edukacyjno-zawodowe i zatrudnieniowe uczniów szkót zawodowych, „Szkoła - Zawód - Praca” 2015, nr 10.

Suchorab A., Wptyw zadań z zakresu orientacji i poradnictwa zawodowego realizowanych w szkole ponadgimnazjalnej na wybory edukacyjno-zawodowe studentów, „Szkoła Zawód - Praca" 2012, nr 3.

Szaban J., Rynek pracy w Polsce i Unii Europejskiej, Difin, Kraków 2013.

Ustawa z 14 grudnia 1994 roku o zatrudnieniu i przeciwdziałaniu bezrobociu Dz. U. z 2001 r. Nr 6, poz. 56.

Żegnałek K., Metody i techniki stosowane w badaniach pedagogicznych, Wyższa Szkoła Pedagogiczna Towarzystwa Wiedzy Powszechnej w Warszawie, Warszawa 2008. 